\title{
Book Review: Douglas Murray's The Madness of Crowds
}

\author{
LIGIA TOMOIAG \\ Affiliation: Technical University of Cluj-Napoca, Romania \\ The Baia Mare University Centre \\ E-mail: ligiatomoiaga@gmail.com
}

\begin{abstract}
Douglas Murray, the author of The Strange Death of Europe (2017), and The Madness of Crowds (2019; 'expanded and updated edition' in 2020), is one of the leading journalists and authors in Great Britain in the fight of the centre-conservative intellectuals against the 'woke' ideologues. His latest book deals with four of the most controversial issues of today's 'identity ideology': Gay, Women, Race and Trans, showing that such unstable concepts cannot be the solid ground for any serious conversation, or for the social edifice. On the contrary, they are treated in such a way that the danger of totalitarian states is no longer unconceivable; what is more, with the cancel culture of today, it is more likely than not that it will cause a serious backlash in the future, which may reverse some of the advancements of the fight for rights of all kinds.
\end{abstract}

Keywords: ideology, identity, woke, gay, race, women, trans

The publication of The Strange Death of Europe, in 2017 (Murray, 2017), introduced on an international scale the journalist and author Douglas Murray, as a very interesting, yet controversial figure. His ideas regarding identity, the Islam, and immigration were very much against the official narrative of the $E U$, and he was attacked as a far-right racist, even if his book is a very thorough and well-conducted study of Europe as it was then. With his newest book, The Madness of Crowds, published in 2019 and re-published with a copious addition in 2020, Murray comes against such narrative again, as he considers four of the most important ideological bricks of the so-called 'woke' generation in reference to Gay, Women, Race and Trans. These also constitute the four chapters of the book. Each chapter is very well-researched, with an impressive number of references to journals, television interviews, social events, people's testimonies, as well as philosophical, sociological, and psychological studies.

The Introduction gives an account of the Social Justice Movement and the new dogma, 
with the concepts they advance-like intersectionalism, feeling safe/unsafe, being 'harmed' by words, white supremacy, toxic masculinity, and others-which are the pillars of a new kind of dogma, or social religion; such ideologues do not allow any interpretation or critique, but just total, immediate and public acceptance. These are seen by Murray to form the foundation of a new "interpretation of the world through the lens of 'social justice', 'identity group politics' and 'intersectionalism' [which] is probably the most audacious and comprehensive effort since the end of the Cold War at creating a new ideology. ... Even the term itself is set up to be anti-oppositional. 'You're opposed to social justice? What do you want, social injustice?'” (Murray, 2020, pp. 2-3). Such ideas of 'social justice' have become most familiar in the new view of society as formed by 'identity groups'-a new division of people according to race, gender, sexuality, and other such 'group identifiers'. These identity traits function, though, as more than just descriptive characteristics-being black, or being a woman, or being gay is seen as a kind of single trait, as the most important characteristic, defining such people/groups, and allowing them just a certain type of reaction, conviction and social activism. The newspeak of most such representatives of the new ideology will make them commence their speeches with 'Speaking as a... ', which somehow also means 'being better than anyone who does not share into such identity'. Those who do not have the 'experience' of identifying as a member of such a group, are not 'on the right side of history'.

Douglas Murray uses a very convincing metaphor, when he refers to the gay rights movement and to the women's rights movement, which have done much progress in the past half-a-century, and which seemed to have arrived at a long hoped-for destination; like a train that arrives in a station. At the moment of arrival, though, the train starts speeding and is derailed, and the whole fight seems to be at the very beginning-people today are declared to be more homophobic, more misogynistic, and more bigoted than ever before, as if the entire advancement in the domain did not exist. The same is maintained in reference to race relations, as if racism is now worse than ever before (it is even 'systemic'). This is how the 'movement' has persuaded the media to reflect on reality:

Having begun to view everything through the new lenses we have been provided with, everything is then weaponized, with consequences which are deranged as well as dementing. It is why The New York Times decides to run a piece by a black author with the title: 'Can my children be Friends with White People?' And why even a piece about cycling deaths in London written by a woman can be framed through the headline: 'Roads Designed by men are Killing Women'. (Murray, 2020, p. 4). 
These stories across all media, especially in the United States and the Great Britain, will make divisions even deeper, and weary of each other. For some people, these concepts and tribulations have translated into very painful realities-they have lost their jobs, their careers were brought to an end, they have even been questioned by the police for 'crimes' that have only to do with not conforming with the narrative. Public figures, artists, writers, or even very average people are being accused of being 'bigots', 'homophobes', 'transphobes', 'sexist'-and the list may continue-while the activists are courageously fighting with such expressions of 'social retardedness', and demonstrate their 'progressive' views at all times. Murray refers to the Australian political philosopher Kenneth Minogue, who was the first to speak about 'St. George in retirement' syndrome:

After slaying the dragon the brave warrior finds himself stalking the land looking for still more glorious fights. He needs his dragons. Eventually, after tiring himself out in pursuit of ever-smaller dragons he may eventually even be found swinging his sword at thin air, imagining it to contain dragons. If that is a temptation for an actual St George, imagine what a person might do who is no saint, owns no horse or lance and is being noticed by nobody. How might they try to persuade people that, given the historical chance, they too would without question have slain that dragon? (Murray, 2020, p. 7)

In fact, the four chapters of the book do nothing else but show how all these apparently 'new' ideas-sometimes using new names-started as legitimate campaigns and activism for human rights. What happened was that activists, NGO's, politicians, academics in the fields of all kinds of 'studies' (women's, queer', etc.) could not just stop, or settle (Murray's term) for equal rights, even if equal rights was what they had been fighting for. They started maintaining the idea that their 'groups' are 'better', that majorities have to somehow pay for historical wrong-doings, that if in the past things were not very well arranged, now 'it is our time', when 'they will pay'. Little do such activism care that the ones they want to make 'pay' are not the ones who actually might have been to blame-which, is also questionable, because today's filter cannot be applied on people's mentalities and behaviour of the past. Those who do not conform to the new ideas and the new speech laws will not benefit from any kind of indulgence-as there is no freedom of speech, and no freedom of conscience, either. One has not only to behave nicely, but admit to their inner 'faults', repent publicly and be vocal in supporting the movement. Who is not 'with us' is not just silent, but 'against us'. It does not matter what one believes, they have to 'bend the knee' (as so many did in summer once that the BLM movement asked for it).

For younger people, as Murray shows, who have a very limited knowledge of history, such ideas are new, they can blame older generations, as they do not understand that 
due to their development and fight society has arrived to this moment of 'illumination'. For those who experienced communism, or other totalitarian regimes, though, things are more visible:

There is something demeaning and eventually soul-destroying about being expected to go along with claims you do not believe to be true and cannot hold to be true. If the belief is that all people should be regarded as having equal value and be accorded equal dignity, then that may be all well and good. If you are asked to believe that there are no differences between homosexuality and heterosexuality, men and women, racism and anti-racism, then this will in time drive you to distraction. That distraction-or crowds madness-is something we are in the middle of and something we need to try to find our way out from" (D. Murray, 2020, p. 9)

The four chapters, referring to gay, women, race and trans explore how activism has transformed real and very sensitive issues, which are still debated and debatable, into indisputable realities that have to be acknowledged as such. The issues that constitute the basis for all these fights and for such radical activism, are in an ever changing status: they are not fixed, they are bound to change and evolve together with the changes and evolution of our entire humanity. If we just agree to the fact that they are fixed in the manner in which they are today presented, as if they have never been known before-like relations between men and women, for instance-and we consider being gay a matter of software and being trans a matter of hardware, in time people might start reacting and a backlash to many democratic and juridical advances might be destroyed. If further atomization happens, people will be more and more enraged, and the silence of today of so many might become violent action tomorrow.

Douglas Murray advocates for two very important human qualities our society needs these days: social trust and forgiveness. Without being able to forgive mistakes of the past, without trusting that those who advance certain policies actually do want to see them through, without trusting that what has already been gained is good and solid, there is very little chance that we get out of this 'madness'. He also considers that intellectuals, authors, independent observers such as himself, as well as other people should resist this 'woke-ism', denounce it courageously, or, at least, not join the 'mad crowds'.

\section{References}

Murray, D. (2020). The Madness of Crowds: Gender, Race and Identity. Bloomsbury Continuum.

Murray, D. (2017). Strange Death of Europe: Immigration, Identity, Islam. Bloomsbury Publishing Plc. 